\title{
La película que no fue
}

\author{
Entrevista a Nicolás Sarquís \\ por Jimena Néspolo ${ }^{\bullet}$ \\ Universidad de Buenos Aires - CONICET
}

Cuando Selva Almada me comentó, a comienzos del año 2016, que estaba escribiendo una crónica sobre el rodaje de Zama (en adaptación de Lucrecia Martel) recordé de pronto esta entrevista que hice al cineasta Nicolás Sarquís ${ }^{1}$, mucho antes de empezar a investigar en serio la obra de Antonio Di Benedetto. Aquella tarde de noviembre de 1997 en que Graciela Lucero, la última compañera del escritor, me acompañó a conocer a Sarquís se hizo presente en mí con emotiva densidad. Esa casa verde de la calle Bulogne Sur Mer, la generosidad de Graciela al ofrecerme numerosas fuentes, materiales de lectura y hacerme partícipe de $s u$ historia con Di Benedetto, la ansiedad ante aquel círculo de amigos que de pronto se abría a mí para referirme libros, películas, anécdotas que no había visto, ni había leído, ni tampoco había escuchado mentar en los pasillos de la facultad de Filosofía y Letras... En aquella época, Di Benedetto era un escritor de culto que cualquier lector de a pie podía no conocer o acaso confundir con Mario Benedetti o con Antonio Dal Masetto, y yo era una periodista veinteańera que vendía notas y entrevistas por aquí y por allá, intentando filtrarme — con más fracasos que éxitos- en el periodismo cultural. Por supuesto, no pude colocar esta entrevista (no tenía color, filigranas de glamour, ni cuadraba con ninguna «noticia» de su presente); no obstante al año siguiente, un golpe de timón cambió mi suerte y me hizo poseedora de una beca para iniciar estudios de doctorado bajo la dirección de Beatriz Sarlo. Con todo, al comenzar a estudiar la obra de Di Benedetto intenté correrme del registro de los anecdotarios sentimentales y olvidé sin más esta grabación.

\footnotetext{
- Doctora en Letras por la Universidad de Buenos Aires. Investigadora de CONICET. Desde 1999 dirige la revista Boca de Sapo. Publicó los ensayos Ejercicios de pudor. Sujeto y escritura en la narrativa de Antonio Di Benedetto (Adriana Hidalgo, 2004) y Tracción a sangre. Ensayos sobre lectura y escritura (Katatay, 2014). Realizó las ediciones críticas de los cuentos de Antonio Di Benedetto y de Eduarda Mansilla. Ha dictado cursos y seminarios en la Universidad de Buenos Aires (Argentina), la Universidad de Granada (España) y en la Universidad Ca'Foscari de Venecia (Italia), entre otras casas de estudio.
} 
Hace poco di por casualidad con el casette de este audio que por alguna razón desconocida se ha salvado de las re-grabaciones en las que incurría en aquellos tiempos (hice cantidades de entrevistas cuyos registros perdí, exigida por la necesidad de tener un soporte), y se lo entregué a Selva sin escucharlo siquiera, a ver si podía llegar a encontrar algo interesante en la cinta. La profesora Adriana Cristina Crolla se ha enterado de la existencia de este archivo y me invita ahora, generosamente, a compartirlo. Accedo, con la esperanza de que sea útil para los especialistas del área y de que estos sepan ser benévolos con la ignorante periodista que soy y que fui.

\section{Entrevista a Nicolás Sarquís (noviembre de 1997)}

Contame cuándo lo conociste... ¿fue a propósito de Zama? ¿En qué año?

Bueno, han pasado tantos años ya... pero fue alrededor de los años '70 que yo leí la primera edición de Zama, que hizo Prelooker ${ }^{2}$, que era un editor fue muy interesante e importante en aquel tiempo porque editaba a escritores argentinos no conocidos. Leí esa novela en la primera edición, tenía la tapa rosada con letras negras - lo recuerdo muy bien-, leí de una sentada esa obra que me pareció extraordinaria... No sabía quién era Di Benedetto, no tenía idea quién era, siendo que —en fin- he leído siempre mucho y me interesó siempre la literatura. En aquellos años yo estaba filmando la muerte de La muerte de Sebastián Arache y su pobre entierro ${ }^{3}$. Comenté con Saer sobre esta novela que por supuesto él ya había leído, y tenía una opinión muy entusiasta sobre este escritor que por aquellos años no era tan conocido...

¿Saer tampoco lo conocía personalmente?

Sí, había leído la novela pero no lo conocía... Y cuando le comenté a Saer la lectura que había hecho de Zama hablamos largo y tendido, y después me dediqué a buscarlo. Yo sabía que era mendocino, así que viajé a Mendoza. En aquel tiempo Antonio era subdirector del diario Los Andes, lo fui a buscar a la redacción, lo ubiqué previamente por teléfono, y esa noche me invitó a un restaurante chino. Tuvimos una extendida, larga charla de sobremesa, y luego me acompañó al hotel donde yo paraba esa noche y el día siguiente también, fuimos caminando, no hablamos más que de cine y de literatura. Teníamos muchas afinidades en cuanto a escritores, por supuesto que sabía bien quién era Saer ya en aquel momento, tenían como una recíproca admiración a la distancia — diría - porque no se conocían personalmente. Yo fui con la idea de proponerle hacer una película sobre Zama: le gustó mucho la idea, algo me conocía a mí. Y estuve compartiendo, desde ese día en que cenamos, largas charlas varios días más hasta que nació no sólo una relación personal sino una relación entrañable con Antonio. Nos hicimos muy amigos. Fue uno de los amigos que más sentí que haya muerto. Después leí toda su obra y me di cuenta que estaba ante uno de los escritores más importantes de Hispanoamérica. A Zama yo la fui trabajando en varias etapas, en largas, prolongadas y sucesivas etapas. Hablé con Saer de la adaptación, con Roa Bastos, con Haroldo Conti... 


\section{¿Di Benedetto colaboró con el guion?}

Cuando yo ya tuve una especie de guion, de tratamiento cinematográfico de la novela, lo leyó, le gustó. Le propuse en varias oportunidades que trabajáramos juntos en el guion, él ya tenía mucha afinidad con el cine porque era un hombre que veía mucho cine, incluso había estado en festivales internacionales como corresponsal del diario Los Andes, pero siempre fue remiso a trabajar él en forma directa.

\section{Ya había trabajado sobre El juicio de Dios, ¿no?}

No, no, eso fue muy posterior. Bueno, después de todos esos tratamientos que hice, en los cuales yo tuve más que una colaboración directa, como charlas con Saer, con Roa y con Haroldo acerca del tratamiento fílmico de la novela, hasta que comencé a rodarla en Paraguay luego de una trabajosa y ardua producción... porque, bueno, es una historia que transcurre en lo que supuestamente es Asunción. Esa película tuvo muchos problemas, yo tuve muchos problemas en Paraguay: era la época de Stroessner ${ }^{4}$, tenía los servicios persiguiéndome todo el tiempo, reclamándome cosas. En fin, la cuestión es que tuve que interrumpir la filmación al cabo de dos semanas de rodaje. Qué casualidad que ahora vos me llames para esto, porque recién la semana pasada yo tuve una copia en video de las semanas de rodaje que filmé en el '81, es decir hace dieciséis años. Los negativos quedaron extraviados, los recuperé y ahora tengo esas imágenes que por primera vez vi después de tantos años.

\section{¿Se pueden ver?}

No... lo que yo hice en otro momento, con la intención de recuperar la producción, en los 500 años del Descubrimiento de América, presenté esta historia como para poder terminarla e hice un compendio de imágenes 5 . Estas imágenes que vi ayer o antes de ayer son imágenes en crudo de todo el material que filmé, alrededor de una hora de filmación. Antonio alcanzó a ver parte de estas imágenes...

\section{¿Cuándo volvió de España?}

Recién salía de estar encarcelado y estuvo viviendo en mi casa, en España.

\section{¿Vos te exiliaste en qué año?}

En el '77, en febrero del '77.

\section{¿Y la filmación es del año...?}

Y la filmación fue anterior a esto... a ver me confundo las fechas, antes de esa fecha, en el ' 75 , en el ' $74^{6}$.

\section{¿Y allá se encontraron?}

Sí, en España nos encontramos. Él acababa de salir de la cárcel; yo desde allá le hice avisar que se viniera a España como sea. Hubo gente que colaboró en ese viaje, como el caso de Ernesto Sabato... Bueno la cuestión es que cuando llegó 
a España vivió en mi casa un tiempo, después empezó a despegarse un poco de todo este drama que había vivido. Y... viajó mucho por Europa, estuvo dando conferencias, estuvimos juntos incluso en Alemania, en un congreso que hubo en la Selva Negra ${ }^{7}$. La cuestión es que en todo ese periplo que vivimos muchos de nosotros en los ańos de la dictadura militar nos vimos muchísimo, estuvimos mucho tiempo frecuentándonos, Di Benedetto incluso estuvo viviendo en mi casa...

\section{¿Y cuándo volvieron?}

Volví en el '81, estuve cuatro años, él todavía seguía en España y ya quería volver también él, una vez que estuviera seguro de que podía venir sin problemas. Yo organicé la recepción que se le hizo a Antonio en aquellos años, con escritores jóvenes, como el caso de Ricardo Piglia, Miguel Briante, Enrique Medina y varios más. Fue muy emocionante esa llegada... ${ }^{8}$ [Silencio] Me paré porque me estoy equivocando las fechas. Zama lo empecé a filmar en el '81, '82... Fue un drama esa producción.

\section{No importa, después lo chequeo. ¿Fue con un préstamo?}

Sí, sí, pero en la época en que había una inflación galopante, donde un kilo de yerba a la mañana valía un peso y a la tarde valía dos pesos: una cosa espantosa esa, la hiperinflación. Se me escapó la película de nuevo, pero sobre todo por problemas políticos de allá. De algún modo tenía requerimientos y exigencias que tenían que ver con determinados actores que en Paraguay no podían trabajar, unos sí, otros no... Tuve muchos problemas de ese tipo, hasta que de la embajada argentina me dijeron «mirá, acá no vas a poder filmar». Yo ya había invertido mucho dinero; la cuestión es que al cabo de tres o cuatro semanas de estar en Paraguay se tuvo que interrumpir el rodaje y me quedé muy mal, al punto que hasta desistí, en ese momento dije «no hago más cine». Fue una cosa muy traumática para mí, tal vez es por eso que me estoy equivocando las fechas, porque no lo quiero recordar... Bueno, la cuestión es que Antonio vio las primeras fotografías de Zama y cuando las miraba decía «es tal cual yo me imaginaba la película». Me alegró que me haya dicho eso. No tuvo suerte Antonio con el cine porque en aquel entonces se empezó a filmar, bueno, ya se había empezado a filmar hacía un tiempo, El juicio de Dios.

\section{Donde murió uno de los actores...}

Sí, murió Ángel Magaña, después se interrumpió la película, apareció un pariente, creo que el yerno de Magańa queriéndola terminar en homenaje a su suegro. Antonio fue consultado para esto, y me pidió que leyera el guion: lo leí.

\section{¿El guion era de él?}

No, no era de él.

Porque él ya lo había adaptado ${ }^{9} . .$.

Sí, sí, yo lo tengo, pero ese no era el guion, era un guion nuevo. Bueno, yo lo leí, vi las imágenes filmadas hasta el momento y escribí otro guion, tomando como base 
aquello que estaba filmado como para poder integrarlo, porque esto fue mucho después - la idea de terminar esa película. Ya estaba todo listo y pronto para ser filmado ese nuevo guion, refundido con lo que ya se había hecho, pero tampoco se concretó.

¿A cargo de quién estaba la dirección de la primera?

Hugo Fili ${ }^{10}$, creo que se llamaba. Yo escribí un guion nuevo que a Antonio le gustó pero que tampoco se hizo, así que también quedó en el olvido. Bueno, después Antonio estuvo unos cuantos meses acá en Buenos Aires, un par de años tal vez, viendo cómo reubicarse después del exilio forzado que tuvo y después de toda esa experiencia que vivió en la cárcel... Por supuesto que nos veíamos muchísimo, casi diariamente, vivimos muchas cosas en común. Hasta que finalmente cayó enfermo, casi repentinamente. Yo estuve junto a él, he vivido muy cerca todo. Me acuerdo que fue un domingo cuando me llamó Graciela Lucero, fui hasta la casa, un departamento que tenían en la calle Laprida, ahí lo internamos y bueno, desde ese día que fue un domingo a la noche, estuvo durante un mes internado en el Hospital Italiano hasta que murió. Me acuerdo que cuando lo acompañaba en la camilla me dice «se me parte la cabeza, espero que esto termine de una vez por todas", eso fue como una despedida... Después ya quedó en un estado imposible de recuperar. Bueno, no recuerdo exactamente si vio imágenes o fotografías de Zama, pero él se quedó con la esperanza de que su película se terminara y yo con la expectativa de terminarla alguna vez.

\section{¿Todavía la tenés?}

Sí, absolutamente. Uno siempre tiene películas postergadas, y esta es mi deuda mayor: en lo personal y también con Antonio Di Benedetto. Curiosamente se fue cumpliendo esa sentencia que encabeza la novela, dedicada «a las víctimas de la espera». Pero bueno, es un proyecto que atesoro, guardo y que tengo muy presente todo el tiempo, y espero poder hacer. Es tal vez la película en la que más esperanzas tengo: como proyecto personal, cultural, artístico, estético, ideológico.

\section{¿Cómo era Di Benedetto como persona?}

Era un hombre entrañable, con mucho sentido del humor. Era además un conquistador — como yo le decía - profesional. Tenía una voz muy grave, pausada, con manos generosas y blandas, pero muy cálidas, era muy lúcido y de una lealtad realmente admirable, y muy consecuente con sus ideas. Y un hombre, también, sin rencores eh, porque después de haber vivido todo lo que vivió podría haber tenido mucho resentimiento con eso... fue una etapa muy dura de su vida, de la que no quería hablar mucho, tampoco. Yo jamás me atreví a preguntarle nada sobre lo que vivió en la cárcel, aun cuando llegaban datos por referencias de otras personas que convivieron en la cárcel con él. Lo que sí le pregunté en aquella ocasión cuando salió y vino a vivir a mi casa en España, si sabía algo de Haroldo Conti. Eran años muy confusos, donde la gente desaparecía, no se sabía a ciencia cierta si estaban en la cárcel, si habían desaparecido, si habían muerto... Me acuerdo que él me dijo que escuchó dentro de la cárcel rumores de que a Haroldo le habían cortado las manos y que se lo había escuchado gritar mucho. Pero no estaban en la misma 
cárcel, él estaba en La Plata. Pero después por pudor, me parecía que era impúdico preguntarle, no le pregunté nunca nada de eso, no me atreví a preguntarle, o sea que siempre se aludía a eso. Pero era un hombre de una generosidad muy grande; era también alguien que se cuestionaba todo el tiempo, se auto-cuestionaba. Antonio fue muy autocrítico de sí mismo, no sólo en lo que escribía sino en su vida particular, privada. Tenía una conciencia moral muy presente en todo momento.

\section{¿Conciencia moral?}

Sí, a ver... como que Antonio tenía dentro de sí una persona que lo vigilaba, que era él mismo. Tal vez trasgredía las normas que se dictaba a sí mismo, pero tenía una conciencia lúcida y ética que parecía, en este mundo de hoy, pertenecer a otra época. Un hombre cabal y un escritor, realmente, fuera de lo común.

\section{¿Y políticamente? ¿Por qué fue encarcelado ${ }^{11}$ ?}

Por confusión. Eran tiempos en que si te agarraban la agenda — no la electrónica, que hubiera sido más difícil descifrarla—, y aparecía un nombre... No sé si por el hecho de ser director de un diario, que tampoco podía considerarse en esa época como "subversivo", Los Andes era un diario tradicional de Mendoza y lo sigue siendo. Por el mero hecho de pensar, quizá, que siempre fue irritativo para la dictadura y los militares.

\section{¿Y los rumores... sobre ese asunto sentimental y el marido traicionado ${ }^{12}$ ?}

Noooo. Antonio era un seductor en el sentido mejor del término. Era un hombre que tenía en su personalidad un modo de ser que era atrayente, porque era muy ocurrente y muy lúcido, y con esa voz gruesa, pausada, envolvente, producía una imantación en la gente, y con las mujeres tenía mucho éxito, aun cuando él se consideraba un hombre feo. Una cosa contradictoria que tenía...

\section{¿Estuvo casado y tuvo una hija? Se separó...}

Sí, la primera mujer murió hace unos años. Y su hija... a quien yo hice venir para su regreso a Argentina: yo le quise dar una sorpresa y la hice venir al aeropuerto porque él no tenía una relación fluida con ella. Fue muy conmovedor. Cuando bajó del avión... había un salón vip con escritores jóvenes, y también la hija. Fue muy conmovedor todo eso. A tal punto que recuerdo que cuando varios días después, íbamos a comer a un restaurante o nos tomábamos un taxi para un lado u otro, a tal punto le había tocado a la gente lo que se había publicitado, lo que había salido en televisión sobre la llegada de Antonio Di Benedetto, que mucha gente lo reconocía en la calle. Nos pasó muchas veces, y él estaba sorprendido por cómo la gente lo reconocía con esa llegada triunfal, entre comillas, después de haber pasado ese calvario que vivió en la cárcel, que lo marcó mucho. Creo que Antonio fue una víctima de la dictadura a destiempo. Su desaparición fue posterior, tardía. Eso que vivió en la cárcel un hombre como Antonio Di Benedetto es algo tan irracional, tan impensable que le haya ocurrido... No era un hombre militante, ni adscripto a 
una corriente política, era simplemente un escritor muy admirado en su provincia, pero también muy particular por su personalidad. Recuerdo que muchos mendocinos de aquel entonces, actores y gente de la clase intelectual, cuando íbamos a determinados lugares juntos, que Antonio Di Benedetto saliera de su cenáculo que era el diario y visitara personalmente todos esos lugares [les] sorprendía a la gente de Mendoza porque él no era un hombre social, era muy reservado. Pero él en lo personal era maravilloso, me divertía mucho con Antonio, a pesar de su gravedad que era como una especie de máscara. Fue uno de mis grandes amigos.

Notas

${ }^{1}$ Nicolás Sarquís (1938-2003) director de cine. Dirigió, entre otros films, Palo y hueso (1967, adaptación de una obra de Juan José Saer), $L a$ muerte de Sebastián Arache y su pobre entierro (1977), El hombre del subsuelo (1981), Facundo, la sombra del tigre (1994) y Sobre la tierra (1998). ${ }^{2}$ Se refiere a la editorial Doble P, fundada por Preeloker, que publica la primera edición de Zama en 1956.

${ }^{3}$ Es posible conjeturar que el encuentro entre Di Benedetto y Sarquís se produjera entre los ańos 1972 y 1974 ya que la película de marras comienza a rodarse en ese ańo, luego se paraliza (por la muerte de un actor: Raúl del Valle) y se reinicia la filmación en 1974, para estrenarse finalmente en 1977 en varios festivales internacionales. La muerte de Sebastián Arache y su pobre entierro fue escrita y dirigida por Sarquís, pero el argumento inicial recibió aportes de Haroldo Conti.

${ }^{4}$ La dictadura de Alfredo Stroessner Matiauda (1912-2006) en Paraguay duró treinta y cinco ańos: de 1954 a 1989. A comienzos de los años noventa, cuando Stroessner ya había sido derrocado, se descubrieron los llamados Archivos del Terror, con documentos que demostraban que el dictador paraguayo había participado en la Operación Cóndor, ese acuerdo militar anticomunista perpetrado desde EEUU para la persecución de exiliados y disidentes políticos, con apoyo de las dictaduras de Argentina, Brasil, Bolivia, Chile, Ecuador y Uruguay durante las décadas de 1970 y 1980.

${ }^{5}$ Ese corto con imágenes de la filmación se proyectó en la Semana de Homenaje a Antonio Di Benedetto, realizada en la Biblioteca Nacional de Argentina, entre el 9 y el 13 de octubre de 2006, organizada por el Instituto de Literatura Hispanoamericana y la Casa de la Provincia de Mendoza.

${ }^{6}$ Sarquís confunde en este momento fechas y situaciones, minutos después se retracta y dice que la filmación fue en el '81. Es posible entonces que Di Benedetto haya visto imágenes pero no en España sino a su regreso del exilio, en Buenos Aires.

${ }^{7}$ Se refiere al Coloquio Alemania Occidental - América Latina - Achern - Selva Negra, que se realiza en el año 1979. Di Benedetto pronuncia la conferencia inaugural.

${ }^{8} \mathrm{Al}$ llegar a Argentina, en 1984, se organiza un Homenaje en el Centro Cultural San Martín donde acuden estos jóvenes escritores. 
${ }^{9}$ En 1959, Antonio Di Benedetto recibe el Segundo Premio de Argumentos para Películas de Largometraje del Instituto Nacional de Cinematografía por su adaptación al cine del cuento «El juicio de Dios», bajo el título Los inocentes.

${ }^{10}$ La película El juicio de Dios se comienza a filmar en 1979 y Ángel Magańa fallece en 1982; Hugo Fili era el director, en rigor; Pedro Marzialetti estaba a cargo de la fotografía y Julio Presas de la música.

${ }^{11}$ Hoy sabemos, a partir del reciente trabajo realizado por Liliana Reales sobre los Escritos periodísticos de Antonio Di Benedetto, que el escritor mantuvo una activa militancia durante la década de 1950 en el Partido Socialista y que incluso llegó a ser candidato a diputado, pero «no se ha encontrado ningún documento o testimonio que pruebe que Di Benedetto tenía alguna militancia política o se hallara cerca de alguna de las organizaciones armadas en la época en que fue encarcelado" (Reales, Liliana. Rastros de una escritura. En Di Benedetto, A. Escritos periodisticos (pp. 15-16). Buenos Aires: Adriana Hidalgo, 2016.). Reales ratifica, a su vez, la tesis de Natalia Gelós (Antonio Di Benedetto periodista. Buenos Aires: Capital Intelectual, 2011), de que los verdaderos motivos de su detención por parte de la Junta Militar, apenas acaecido el golpe el 24 de marzo de 1976, se debieron al tenor y compromiso con la tarea periodística que desempeñaba y, más específicamente, a la postura asumida en los meses previos, cuando la represión, la desaparición de personas y los asesinatos habían desatado ya una ola de terror en el país.

${ }^{12}$ El morbo por la trama sentimental, aquí, supongo que había sido atizado por la propia Graciela Lucero, quien ya me había mostrado la colección de cartas enviadas al autor en sus últimos tiempos, por parte de otras amigas o amantes del pasado.

\section{Apéndice donde escuchar el audio}

https://soundcloud.com/user-805378678/entrevista-a-nicolas-sarquis1997-noviembre

\section{Néspolo, Jimena}

